\title{
REVIEW OF THE WORK "MODERN TATAR SPOKEN LANGUAGE: IDENTIFICATION SIGNS AND SOCIAL DIFFERENCES" BY G. GALIULLINA, E. KADIROVA, G. HADIEVA, 2020. 222 p.
}

\author{
Fanuza Shakurovna Nurieva, \\ Kazan Federal University, \\ 8 Kremlevskaya Str., Kazan, 420008, Russian Federation, \\ fanuzanurieva@yandex.ru.
}

\begin{abstract}
This article reviews the monograph "Modern Tatar Spoken Language: Identification Signs and Social Differences", written by G. Galiullina, E. Kadirova, G. Khadieva, researchers from the Tatar Linguistics Department of Kazan (Volga Region) Federal University and published by the Kazan University Publishing House in 2020. The work explores the peculiarities of the modern Tatar spoken language in the fields of lexicon, phonetics, morphology and syntax. The main focus is on the functional capabilities of language units, widespread in spoken language, and the scope of their distribution. The monograph contains about 1,460 audio recordings of unprepared spontaneous speech patterns by the middle and western dialect representatives of different ages and social statuses. The authors of the monograph managed to distinguish the identifying marks of the modern Tatar spoken language and to determine their distribution in public groups, using complex research techniques. The work promotes the development of the theory of the Tatar language, and makes a significant contribution to the fields of dialectology, communicative linguistics, sociolinguistics and linguoculturology.
\end{abstract}

Key words: Tatar language, spoken language, lexicon, phonetics, morphology, syntax.

The modern Tatar language is among the spiritual and cultural treasures created by the Tatar people over centuries. Being an achievement of folk speech culture, the phonetic structure, word groups, and vocabulary of our language are incredibly rich. Socio-historical events and changes in society have had a certain impact on both the language and its development.

As it is known, the Tatars have not dissolved among other nations over centuries, they are one of the great peoples who have preserved their culture and their language. Our language is still alive today, satisfying the need for communication in all spheres of life of the Tatar people scattered around the world. There are also lexical units in the Tatar language that do not meet literary norms, but are used in the speech of representatives of certain regions and of various social statuses. Language changes, formed during international interactions, first take place in the spoken language; some of the features may spread further and even lead to qualitative changes in the national language.

In the current context of globalization, linguists, working at Kazan Federal University, pay special attention to identifying the state of the Tatar language and to determining the direction of its development in time when boundaries between languages and cultures are blurred. Recently, in
2020, the Kazan University Publishing House published the work "Modern Tatar Spoken Language: Identification Signs and Social Differences" by G. Galiullina, E. Kadirova, G. Khadieva (a monograph, Kazan: Kazan University Press, 2020, p. 222), which is devoted to the study of the Tatar people's daily speech, exploring various layers of the language. It is written in Russian. The introductory part of the collective monograph, its chapters "Theoretical and Methodological Bases of the Study of the Tatar Spoken Language", "Lexical Identification Signs of Modern Tatar Speech" and the conclusion are written by Prof. G. Galiullina, Doctor of Philology. The chapter "Phonetic Identification Signs of the Modern Tatar Speech" is written by G. Khadieva, Candidate of Philology, Associate Professor; the chapter "Grammatical Identification Signs of Modern Tatar Speech" is written by E. Kadirova, Candidate of Philology, Associate Professor. The appendix provides basic linguistic features of the spoken language, speech samples from representatives of various community groups, and examples of the language units' usage in spontaneous speech.

The monograph focuses on identifying the functional features of lexical, phonetic, morphological and syntactic units that are widespread in the Tatar spoken language, and on determining the 
scope of their distribution. I would like to dwell on the linguistic material, used by scholars in this work, which explores the state of the modern spoken language of the Tatar people and its problems. The main factual material consists of 1460 audio recordings of unprepared spontaneous speech samples by representatives of the middle and western dialects of different ages and social statuses. The respondents were grouped according to their education level, gender and age. The division of the recorded speech into the samples of young and middle-aged language speakers allowed the authors to determine the nature and depth of the use of the linguistic features frequently found in the language. In some cases, the data from the "Corpus of the Tatar Language" and the "Corpus of the Tatar Fiction" were also used to substantiate the results. In order to preserve the naturalness (spontaneity) of the recorded speech, communication with informants was carried out under different conditions. The factual material, consisting of audio recordings, is a reliable source in the objective description and scientific substantiation of the state of the modern Tatar spoken language.

The monograph consists of four chapters and an appendix. The first chapter, entitled "Theoretical and Methodological Basis for the Study of the Tatar Spoken Language" (pages 9- 31), discusses the concepts of the literary language, codified in modern linguistics and spoken language. It includes explanations of the spoken language status of such modern linguists as A. Gerd, E. Zemskaya, R. Frumkina and others, definitions and explanations of the scholars who studied the Turkic languages, such as A. Hazratkulov, R. Amirov, M. Khaldarova, B. Urinbaev, S. Khamidova, R. Zhashuev and G. Basyrova. Advances in the study of the Tatar spoken language are systematically covered in the monograph. The issue of spoken language was raised in Tatar linguistics in the late nineteenth century in the studies of S. Kuklyashev, M. Ivanov, K. Nasyri and N. Katanov. In the early twentieth century, G. Ibragimov, G. Alparov, L. Jalay and Sh. Ramazanov studied the issue of spoken language and the use of lexical units related to spoken language. Various aspects of spoken language are clarified in varying degrees in the works of such scholars as M. Zakiev, V. Khakov, H. Kurbatov, I. Bashirova, I. Nizamov and others. F. Safiullina, who thoroughly studied the syntactic features of the Tatar spoken language, defines spoken language as a kind of functional styles characterized by precise style features. In I. Nizamov's works spoken language is called soylamiyat and is studied as an independent system that incorporates the features of the nation's thinking and communication. The authors of the reviewed monograph conclude that the study of spoken language in Tatar linguistics is preferable from the functional style perspective. In the book "Modern Tatar Spoken Language: Identification Signs and Social Differences", the authors examine spoken language within the framework of a particular system set against the literary language.

The chapter "Lexical Identification Signs of Modern Tatar Speech" (pp. 31 -86), in addition to literary and neutral words that occur in free conversations in everyday life of the Tatar people, discusses simple speech vocabulary, dialectal and interregional words, barbarisms, jargon, slang and professional elements of speech. The use of different language units in speech is studied depending on the respondents' place of residence, social status, age, type of education, emotional state and other factors. This approach is set as the main criterion in all sections of the monograph. It includes today's language of the Tatar youth, slang in their language, slogans typical of social groups, barbarisms, universal and asymmetric elements, and numerous examples of words and word forms that have undergone various changes. It is noted that among the units, evaluating semantic and expressive-stylistic features, simple speech vocabulary is actively used in spoken language. The phenomenon of interference, typical of the modern Tatar spoken language, is studied in connection with linguistic conditions, psychological and socio-cultural factors. The results show that the use of words, borrowed from other languages, despite the presence of their full equivalents in the Tatar language, has become commonplace for Tatar speakers, and that there are practically no limitations in the parallel use of the vocabulary of the two languages in bilingual conditions. After reading the monograph, you will be able to get acquainted with personal observations and opinions of the researchers, concerning basic and applied lexical features of the spoken Tatar language.

In communication, information is transmitted by means of vowel phrases - words - that have certain meanings. Communication is provided by voices and supersegment units that play an important role in highlighting the meaning. The current pronunciation rules of phonemes and their use in speech constitute the phonetic norm of the Tatar language. The chapter "Phonetic Identification Signs of Modern Tatar Speech" (pages 87 - 133) examines the phonetic features, observed in the Ta- 
tar spoken language. G. Khadieva shows that characteristic features of the Tatar spoken language are: the intensity of speech, indistinct articulation; the reduction of individual sounds and sound structures; the pronunciation of the open sound [a] in all the positions of the word; the equivalence of the sounds [ə] [i]; the decomposition of the sounds [o], [ö] and the use of the [u], [ü] sounds in their stead; the equivalence of the diphthong [öi] to the sound [i]; the production of the sound between [o] and $[\mathrm{u}]$ instead of the Tatar sound $[\overline{\mathrm{o}}]$ and the approximation of the sound $\left[\mathrm{e}^{-}\right]$to the sound [i]; specific features in the pronunciation of syllables: [ch] $\sim[\mathrm{s}] ;[\mathrm{z}] \sim[\mathrm{s}] ;[\mathrm{F}] \sim[\mathrm{g}] ;[\mathrm{q}] \sim[\mathrm{K}] ;[\mathrm{n},] \sim[\mathrm{n}] ;[\mathrm{d}] \sim$ $[\mathrm{i}] ;[\mathrm{j}] \sim[\mathrm{dj}] ;[\mathrm{h}] \sim[\mathrm{kh}] ;[\mathrm{t}],[\mathrm{d}] \sim\left[\mathrm{t}^{\prime}\right],\left[\mathrm{d}^{\prime}\right]$; the equalization of the sounds $[\mathrm{w}] \sim[\mathrm{b}],[\mathrm{b}] \sim[\mathrm{w}]$; the lack of the labial [a] sound after lip-pulling; the loss of tension, jaw-dropping and variability in a rapid speech process. The scholar explains that the reasons for deviations from the norm, reflected in the speech of the respondents, are related to the influence of dialects, as well as the interference phenomena caused by active bilingualism, in addition to the absence of special letters for each phoneme in the Tatar alphabet. Intonation features play an important role in spoken language: elongation of syllables, changes in speech tempo, a sharp increase and decrease in tone, etc. These features were examined using a Speech Analyze Computer Program.

The section "Grammatical Identification Signs of Modern Tatar Speech" (pages 134-179) explores and analyzes the categories specific to morphology and syntax, and their functional capabilities in spoken language. In this chapter, the scholar E. Kadirova explores the use of independent and auxiliary word groups as a complete system. In the field of noun clusters, the researcher highlights the use of special forms of adverbs in other contexts and the addition of Russian suffixes to nouns in the speech of young people (Reginchik - Regina,
Elchik - Elmira, Alsunchik - Alsu, Enjeshka Enje, Jimeshka - Jimesh, Alsush - Alsu, etc.), the presence of additional adverbs in the adjective group (byyelgysy, hazergese, bugengese), the use of Russian derivatives, for example Babay ul tozhe shundyy obchitel'nyy buldy (male, Kazan, 36 years old), ni, nima, nasta in the spoken language , as well as the active use of the substitutions from the Russian language; the subgroups of the verbs are distinguished from the Tatar literary language and other dialects. In the field of morphology, among the features that distinguish the spoken language from the literary language, the researcher underlines the simplification phenomenon in the language, the influence of dialects and the influence of the Russian language. By providing numerous examples, the "Syntax Section" confirms that deviations from the literary norm, related to sentence construction, are caused by the constant use of Russian-style patterns in speech, which has become a hallmark of modern Tatar spoken language.

Although the monograph is written by a team of authors, the construction of the categories specific to each of the language branches, their functions in the Tatar spoken language are studied on the basis of a single principle, and the language branches are in close contact with each other. As a result, the identification signs of the modern Tatar spoken language have been identified and distributed in groups, based on numerous examples. I would like to note the theoretical substantiation, provided by the authors, and their skill of using live spoken vocabulary in the systemic study of the spoken language, which enabled them to come to general conclusions. Today, in the context of the national strategy for the preservation of the language, the protection of the people and the survival of the nation, the importance of this monograph is particularly timely, as it considers both the modern spoken language of the Tatar people and its future. 


\title{
Г.Р. ГАЛИУЛЛИНА, Э.Х. КАДИРОВА, Г.К. ҺАДИЕВАНЫН «ХӘЗЕРГЕ ТАТАР СӨЙЛӘМ ТЕЛЕ: ИДЕНТИФИКАЦИОН БИЛГЕЛӘРЕ ҺӘМ СОЦИАЛЬ ДИФФЕРЕНЦИАЦИЯСЕ» («СОВРЕМЕННАЯ ТАТАРСКАЯ РАЗГОВОРНАЯ РЕЧЬ: ИДЕНТИФИКАЦИОННЫЕ ПРИЗНАКИ И СОЦИАЛЬНАЯ ДИФФЕРЕНЦИАЦИЯ», 2020. 222 с.) ХЕЗМӘТЕНӘ БӘЯЛӘМӘ
}

\author{
Фәнүзә Шәкүр кызы Нуриева, \\ Казан федераль университеты, \\ Россия, 420008, Казан ш., Кремль ур., 18 нче йорт, \\ fanuzanurieva @yandex.ru.
}

\begin{abstract}
Бәяләмәдә Казан (Идел буе) федераль университетының татар теле белеме кафедрасы галимнәре Г.Р. Галиуллина, Э.Х. Кадирова, Г.К. Хадиева авторлыгында 2020 елда Казан университеты нәшриятында басылып чыккан «Хәзерге татар сөйләм теле: идентификацион билгеләре һәм социаль дифференциациясе» дигән монографиясенә анализ ясала. Хезмәттә лексика, фонетика, морфология, синтаксис тел тармакларында хәзерге татар сөйләм теленә хас күренешләр өйрәнелә. Төп игътибар сөйләм телендә киң таралыш тапкан тел берәмлекләренең функциональ мөмкинлекләре, таралыш даирәсен ачыклауга юнәлдерелгән. Монографиядә кулланылган тел материалын төрле яшьтәге һәм социаль статустагы урта һәм көнбатыш диалекты вәкилләренең алдан әзерләнмәгән спонтан сөйләме яздырып алынган 1460 аудиоязма тәшкил итә. Монография авторлары тикшерүдә комплекслы алымнар кулланып, хәзерге татар сөйләм теленең идентификацион билгеләрен аерып чыгарырга һәм ижтимагый төркемнәрдә таралышын ачыклауга ирешкән. Китап татар теленең теориясен үстерүгә, диалектология, коммуникатив лингвистика, социолингвистика, лингвокультурология өлкәләренә зур өлеш кертә торган гыйльми хезмәт буларак бәяләнергә лаеклы.
\end{abstract}

Төп төшенчәләр: татар теле, сөйләм теле, лексика, фонетика, морфология, синтаксис.

Хәзерге татар теле гасырлар дәвамында халкыбыз тарафыннан ижат ителгән рухи һәм мәдәни хәзинәләрдән санала. Халык сөйләм мәдәниятенең казанышы буларак телебезнең аваз төзелеше, сүз төркемнәре, сүзлек составы гажәеп дәрәжәдә бай булып оешкан. Ижтимагый-тарихи вакыйгалар, жәмгыятьтәге үзгәрешләр телгә дә, аның үсешенә дә билгеле күләмдә йогынты ясыйлар.

Билгеле булганча, татарлар күп гасырлар дәвамында башка халыклар эчендә эреп югалмаган, ул - үз мәдәниятен һәм үз телен саклап калган бөек халыклардан. Дөньяга сибелгән татар халкының тормыш-көнкүрешенең барлык өлкәләрендә аралашу ихтыяжын канәгатьләндереп килгән телебез бүген дә хәрәкәттә. Татар халкының телендә әдәби нормаларга сыймаган, әмма төбәк даирәсенең hәм төрле ижтимагый катлам вәкилләренең сөйләмендә кулланылган берәмлекләр дә урын ала. Халыкара актив багланышлар заманында телдә барлыкка килә торган үзгәрешләр, иң әүвәл сөйләм телендә урын ала, кайбер үзенчәлекләр, киң таралыш алып, хәтта милли телнең сыйфат ягыннан үзгәрешенә китерергә мөмкин .

Казан федераль университетында эшләүче тел галимнәре бүгенге глобальләшү шартларында, телләр һәм мәдәниятләр арасында чикләр жуелган заманда татар теленең торышын ачыклауга, үсеш-үзгәреш юнәлешләрен билгеләүгә аеруча зур игътибар бирә. Әле яңа гына, 2020 елда, Казан университы нәшриятында татар халкының көндәлек аралашудагы сөйләм теленең тел ярусларының төрле катламнарына караган күренешләр тикшерелгән «Хәзерге татар сөйләм теле: идентификацион билгеләре һәм социаль дифференциациясе» (Г.Р. Галиуллина, Э.Х. Кадирова, Г.К. Хадиева. Современная татарская разговорная речь: идентификационные признаки и социальная дифференциация: монография. Казань: Издательство Казанского университета, 2020. 222 с.) хезмәте нәшер ителде. Ул рус телендә язылган. Коллектив монографиянең кереш өлешен, «Татар сөйләм телен өйрәнүнең теоретик-методологик нигезләре», «Хәзерге татар сөйләменең лексик идентификацион билгеләре» бүлекләрен һәм йомгагын - 
филология фәннәре докторы, профессор Г.Р. Галиуллина, «Хәзерге татар сөйләменең фонетик идентификацион билгеләре» бүлеген филология фәннәре кандидаты, доцент Г.К. һадиева, «Хәзерге татар сөйләменең грамматик идентификацион билгеләре» бүлеген филология фәннәре кандидаты, доцент Э.Х. Кадирова язган. Кушымта өлешендә сөйләм теленең төп лингвистик билгеләре, төрле ижтимагый төркем вәкилләренең сөйләм үрнәкләре һәм спонтан сөйләмдә тел берәмлекләренең кулланылышына мисаллар китерелгән.

Монографиядә төп игътибар татар сөйләм телендә киң таралыш тапкан лексик, фонетик, морфологик, синтаксик берәмлекләрнең функциональ мөмкинлекләрен ачыклауга, таралыш даирәсен билгеләүгә юнәлтелгән. Татар халкының хәзерге сөйләм теленең торышын ачыклаган, проблемаларын барлаган әлеге хезмәттә галимнәр файдаланган тел материалын аерым билгеләп үтәргә кирәк дип саныйм. Хезмәттә төп фактик материалны төрле яшьтәге һәм социаль статустагы урта һәм көнбатыш диалекты вәкилләренең алдан әзерләнмәгән спонтан сөйләме яздырып алынган 1460 аудиоязма тәшкил итә. Респондентлар белем дәрәжәсе, женесе һәм яше буенча төркемләнгән. Сөйләмне яшьләр һәм урта яшьләрдәге тел вәкилләренә бүлү телдә киң таралыш тапкан hәм сөйләм теленең аерым бер үзенчәлекле ягы буларак саналырга хаклы тел үзенчәлекләренең асылын һәм кулланылыш тирәнлеген ачыкларга мөмкинлек биргән. Аерым очракларда, нәтижәләрен нигезләү өчен, «Татар теленең язма корпусы», «Татар матур әдәбияты корпусы» материаллары да файдаланылган. Сөйләмнең табигыйлеген (спонтанлыгын. - acc. Ф.Н.) саклау максатында, информантлар белән аралашу төрле шартларда уздырылган. Аудиоязмалардан торган фактик материал хәзерге татар сөйләменең торышын объектив тасвирлауда, фәнни нигезләүдә ышанычлы чыганак булып тора.

Монография дүрт бүлектән һәм кушымта өлешләреннән тора. «Татар сөйләм телен өйрәнүнең теоретик-методологик нигезләре» дип аталган беренче бүлектә (9-31б.) хәзерге тел белемендә кодификацияләнгән, ягъни нормаларга салынган әдәби тел һәм сөйләм теле төшенчәләре карала. Хәзерге заман лингвистикасында рус галимнәреннән А. С. Герд, Е. А. Земская, Р. М. Фрумкина һ.б., төрки телләрне өйрәнгән галимнәрдән А. А. Хазрат- кулов, Р. С. Амиров, М. Халдарова, Б. У. Уринбаев, С. М. Хамидова, Р. Б. Жашуев, Г. А. Басырова хезмәтләрендә сөйләм теленең статусы хакындагы өйрәтмәләр урын алган. Татар сөйләм телен өйрәнү өлкәсендәге казанышлар хезмәттә системалаштырылып яктыртылган. Татар теле белемендә сөйләм теле мәсьәләсе инде XIX гасыр ахырына таба С. Күкләшев, М. Иванов, К. Насыйри, Н. Катанов хезмәтләрендә күтәрелә башлый. XX гасыр башларында сөйләм теле мәсьәләсе, сөйләм теленә караган лексик берәмлекләрнең кулланылыш үзенчәлекләре Г. Ибраһимов, Г. Алпаров, Л. Жәләй, Ш. Рамазанов хезмәтләрендә күтәрелә. Сөйләм теленең төрле аспектлары М. З. Зәкиев, В. Х. Хаков, Х. Р. Курбатов, И. Б. Бәширова, И. М. Низамов һ.б. галимнәрнең хезмәтләрендә төрле дәрәжәдә яктыртылган. Сөйләм теленең синтаксик үзенчәлекләрен әтрафлы өйрәнгән Ф. Сафиуллина сөйләм телен төгәл стиль үзенчәлекләре белән характерланган функциональ стильләрнең бер төре итеп карый. И. Низамов хезмәтләрендә сөйләм теле сөйләмият дип аталып, милләтнең фикерләү һәм аралашу үзенчәлекләрен туплаган мөстәкыйль система буларак өйрәнелгән. Бәяләнә торган монография авторлары татар тел белемендә сөйләм телен функциональ стильләр күзлегеннән тикшерү өстенлек алган дигән нәтижәгә килгән. «Хәзерге татар сөйләм теле: идентификацион билгеләре һәм социаль дифференциациясе» китабында авторлар сөйләм телен нормалашкан әдәби телгә каршы куелган аерым бер система чикләрендә тикшеpə.

Татар кешеләренең ирекле әңгәмәләрендә, көндәлек тормышында урын алган әдәби, гомумкулланылыштагы сүзләрдән тыш гади сөйләм лексикасы, диалекталь һәм төбәкара сүзләр, варваризмнар, жаргон, сленг, профессиональ һ.б. сөйләм элементлары «Хәзерге татар сөйләменең лексик идентификацион билгеләре» (31-86 б.) бүлегендә карала. Сөйләмдә төрле тел берәмлекләренең кулланылуы респондентларның яшәу урынына, социаль статусына, яшенә, белем дәрәжәсенә, эмоциональ торышына һәм башка факторларга бәйле өйрәнелгән. Бу караш хезмәтнең барлык бүлекләрендә төп критерий буларак куелган. Хезмәттә бүгенге татар яшьләренең сөйләме, алар телендә урын алган сленг, ижтимагый төркемнәргә хас жаргон, варваризмнар, универсаль һәм асиментик элементлар, төрле Үзгәртүләргә дучар булган сүз һәм сүз 
формаларының күпсанлы үрнәкләре урын алган. Семантик һәм экспрессив-стилистик бәя бирә торган берәмлекләрдән, гади сөйләм лексикасының сөйләм телендә аеруча актив кулланылышы күрсәтелгән. Хәзерге татар сөйләм теленә хас интерференция күренеше лингвистик шартлар, психологик һәм социомәдәни факторлар бәйләнешендә өйрәнелгән. Татар телендә эквивалентлары булуга карамастан, башка тел сүзләрен файдалану татарча сөйләшүчеләр өчен гадәти күренешкә әйләнүен, билингваль шартларда ике тел лексикасын янәшә куллануда чикләр жуела баруын күрсәткән нәтижәләр бүгенгене күзаллап, киләчәкне кайгыртырга кирәклеген кисәтә. Монографияне укыгач, галимнең шәхси күзәтүләре һәм үзенчәлекле фикерләре белән ныклап таныша алачаксыз, анда хәзерге татар сөйләм телендә киң таралыш тапкан һәм сөйләм теленең аерым бер үзенчәлекле ягы буларак саналырга хаклы лексик үзенчәлекләрнең асылы һәм кулланылышы тулы бер система итеп бирелгән.

Аралашуда мәгълүмат билгеле бер мәгънәләргә ия булган аваз тезмәләре - сүзләр - ярдәмендә тапшырыла. Ягъни хәбәрләшүне мәгънә аеруда мөһим роль уйнаган авазлар һәм суперсегмент берәмлекләр тәэмин итә. Фонемаларның гамәлдә булган әйтелеш кагыйдәләре һәм сөйләмдә алардан файдалану татар теленең фонетик нормасын тәшкил итә. «Хәзерге татар сөйләменең фонетик идентификацион билгеләре» (87-133 б.) бүлегендә татар сөйләм телендә күзәтелгән фонетик үзенчәлекләр тикшерелә. Галимә Г.К. Һадиева татар сөйләм теленең характерлы билгеләре итеп сөйләмнең кызу темпын, артикулияциянең ачык булмавын, аерым авазларның һәм аваз төзелмәләренең редукцияләнүен күрсәтә. Сөйләмдә сузыклар әйтелешенә хас булган сүзнең барлык позицияләрендә ачык [а] авазы әйтелү, [ә] [и] авазларының тәңгәллеге, [о], [ө] авазларының иренсезләшүе, алар урынына [y], [ү] авазлары кулланылу, [өй] дифтонгының [и] авазы белән тәңгәллеге, [ō] авазы татар сөйләмендә [o] hәм [у] арасындарак әйтелү, [э] авазының [и] авазына якынаюы билгеләнгән. Тартыклар әйтелешендә үзенчәлекләр [ч] [c]; [3] [c]; [ғ] $\sim[г] ;[\mathrm{K}] \sim[\mathrm{\kappa}] ;[\mathrm{H}] \sim[\mathrm{H}] ;[$ д] [й]; [ж] [дж]; [h] $\sim[\mathrm{x}] ;[\mathrm{H}] \sim[\mathrm{H}] ;[\mathrm{T}],\left[\right.$ д] $\left.\sim \mathrm{T}^{\prime}\right],\left[\right.$ д’ $^{\prime} ;[$ б] $~[\mathrm{w}] ;[\mathrm{w}] \sim$ [в] авазларының тәңгәлләшүе; ирен-ирен тартыкларыннан соң лабиаль $\left[\mathrm{a}^{\mathrm{o}}\right]$ авазы булмау, ирен-ирен тартыклары янында тартыкларның иренләшмәве, тиз сөйләм процессында кайбер тартыкларның, ижекләрнең төшеп калуы, вариативлык күренешләре белән характерлана. Галимә респондентлар сөйләмендә чагылган нормадан тайпылыш сәбәпләренең диалектлар тәэсире, шулай ук актив икетеллелек нәтижәсендә барлыкка килгән интерференция күренешләре белән бәйлелеген, шулай ук татар алфавитында һәр фонема өчен махсус хәрефләр булмавы белән аңлата. Сөйләм телендә мөһим роль уйнаган интонацион үзенчәлекләр: сузыкларның озынаюы, сөйләм темпының үзгәрүе, тонның кискен күтәрелүе, түбәнәюе, сузылуы h.б. билгеләре Speech Analyze компьютер программасын файдаланып тикшерелгән.

«Хәзерге татар сөйләменең грамматик идентификацион билгеләре» (134-179 б.) бүлегендә морфология һәм синтаксиска хас булган категорияләр, аларның сөйләм телендә башкара торган функциональ мөмкинлекләре барланган һәм анализланган. Әлеге бүлектә галимә Э.Х. Кадирова мөстәкыйль һәм ярдәмлек сүз төркемнәренең кулланылышын тулы бер система буларак өйрәнеп чыккан. Исем сүз төркемнәре өлкәсендә үзенчәлек итеп аерым килеш формаларын башка килеш мәгънәләрендә куллану очракларын, яшьләр сөйләмендә исемнәргә рус теленең иркәләүкечерәйтү кушымчаларын өстәү (Регинчик Регина, Эльчик - Эльмира, Алсунчик - Алсу, Энжсешка - Энжсе, жсимешка - жстимеш, Гайшуля - Гайшә, Алсуш - Алсу һ.б., сыйфат сүз төркемендә өстәмә кушымчалар булу (быелгысы, хәзергесе, бүгенгесе), рус алынмаларын куллану, мәсәлән Бабай ул тоже шундый общчттельнылй булды (ир., Казан, 36 яшь), сөйләм телендә ни, нимә, нәстә, шулай ук рус теленнән кергән алмашлыкларның актив булуы, фигыль төркемчәләрендә татар әдәби теленнән аермалы очраклар һәм башка үзенчәлекләр билгеләнгән. Морфология өлкәсендә сөйләм телен әдәби телгә каршы куя торган үзенчәлекләр буларак телдә экономия күренеше, ягъни гадиләштеру, диалектлар тәэсире, рус теле йогынтысы күрсәтелгән. Синтаксис бүлегендә жөмлә төзелешенә бәйле әдәби нормадан тайпылышлар, рус теленә хас калыпларны механик рәвештә сөйләмдә кулланылышның даими характерда булуы хәзерге татар сөйләм теленең идентификацион билгесенә әверелүе күп санлы мисаллар белән расланган.

Монография төрле авторлар тарафыннан язылса да, тел тармакларының һәрберсенә хас булган категорияләрнең төзелеше, аларның 
татар сөйләм телендә башкара торган функциональ мөмкинлекләре бер принципка нигезләнеп өйрәнелгән, тел тармакларының бер-берсе белән тыгыз мөнәсәбәттә, хәрәкәттә булуы күрсәтелгән. Нәтижә буларак, хәзерге татар сөйләм теленең идентификацион билгеләре аерып чыгарылган һәм ижтимагый төркемнәрдә таралышы ачыкланган, бай мисаллар белән расланган. Сөйләм телен системалы өйрәнеп, гомуми нәтижәләргә килүдә авторларның теоретик әзерлеге һәм жанлы сөйләмә байлыкны файдалана белү осталыгын да билгеләп үтәргә кирәк. Бүгенге көндә телне саклау, халыкны саклау, милләтне яшәтү өчен, милли стратегия кабул ителгән заманда, хезмәтнең әһәмияте аеруча игътибарга лаек, чөнки бәяләнә торган монографиядә татар халкының хәзерге аралашу телен күзаллау да, сөйләм теленең киләчәген уйлау, алга таба хәрәкәт итү юнәлешен билгеләгән фикерләр урын алган.

\title{
РЕЦЕНЗИЯ НА МОНОГРАФИЮ Г. Р. ГАЛИУЛЛИНОЙ, Э. Х. КАДИРОВОЙ, Г. К. ХАДИЕВОЙ «СОВРЕМЕННАЯ ТАТАРСКАЯ РАЗГОВОРНАЯ РЕЧЬ: ИДЕНТИФИКАЦИОННЫЕ ПРИЗНАКИ И СОЦИАЛЬНАЯ ДИФФЕРЕНЦИАЦИЯ», 2020. 222 с.
}

\author{
Фануза Шакуровна Нуриева, \\ Казанский федеральный университет, \\ Россия, 420008, г. Казань, ул. Кремлевская, д. 18, \\ fanuzanurieva@yandex.ru.
}

\begin{abstract}
В рецензии анализируется монография «Современная татарская разговорная речь: идентификационные признаки и социальная дифференциация», вышедшая в издательстве Казанского университета в 2020 году. Авторами являются ученые кафедры татарского языкознания Казанского (Приволжского) федерального университета Г. Р. Галиуллина, Э. Х. Кадирова, Г.К. Хадиева. Работа представляет исследование лексических, фонетических, морфологических, синтаксических особенностей современной татарской разговорной речи. Основное внимание уделяется функциональным особенностям типичных разговорных элементов и степени их распространения в речи. Языковым материалом исследования послужили 1460 аудиозаписей неподготовленной, спонтанной речи татар разной возрастной группы и социального статуса. Благодаря хорошо подобранному и убедительно анализированному фактическому материалу, авторам удалось выявить и описать идентификационные признаки татарской разговорной речи. Монография будет полезна для исследователей теории татарского языка, при разработке проблем диалектного языка, коммуникативной лингвистики, социолингвистики, лингвокультурологии.
\end{abstract}

Ключевые слова: татарский язык, разговорная речь, лексика, фонетика, морфология, синтаксис. 